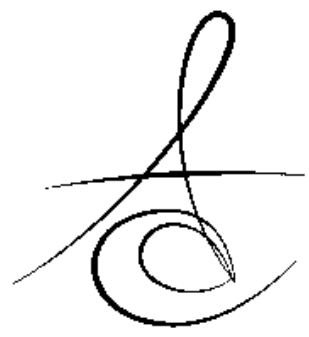

\title{
NİSTATİN VE TİTANYUM DİOKSİT İLAVESİNİN YUMUŞAK ASTAR MATERYALİNDEKİ CANDIDA KOLONİZASYONU ÜZERİNE ETKİSINNINN KARŞILAŞTIRILMASI
}

\section{COMPARISON OF THE EFFECT OF NYSTATIN AND TITANIUM DIOXIDE ADDITION ON CANDIDA COLONIZATION IN SOFT LINING MATERIAL}

\author{
Prof. Dr. Funda BAYINDIR \\ Prof.Dr. Ayşe Esin AKTAŞ*
}

\author{
Yrd. Doç. Dr. Esra KUL* \\ Öğr. Gör. Ayşe BAŞTOPÇU*
}

\begin{abstract}
Makale Kodu/Article code: 3045
Makale Gönderilme tarihi: 02.10 .2016

Kabul Tarihi; $\quad 04.01 .2017$
\end{abstract}

\section{öz}

Amaç: Tam protez kullanan hastalarda, yumuşak astar materyalleri, mukozayı irrite eden lezyon oluşumları ile sonuçlanan, Candida albicans' ların adezyonunu ve kolonizasyonunu destekleyebilir. Bu çalışmanın amacı, nistatin ve titanium dioksit $\left[\mathrm{TiO}_{2}\right]$ antifungal ajanlarının, yumuşak astar maddelerindeki Candida albicans kolonizasyonunu önlemedeki etkisini değerlendirmektir.

Gereç ve Yöntem: Ufi Gel P ve Mollosil yumuşak astar materyallerinden $5 \mathrm{~mm}$ çapında ve $2 \mathrm{~mm}$ kalınlığında, $5 \%$, $10 \%$, and $15 \%$ konsantrasyonda nistatin ve titanyum dioksit içeren diskler hazırlandı. Kontrol grubu için ise nistatin ve $\mathrm{TiO}_{2}$ içermeyen, sadece yumuşak astar maddesinden oluşan diskler hazırlandı. C. albicans' lar Sabouraud Dekstroz Agar (SDA) kaplı besiyerine inoküle edildi. Hazırlanan diskler besiyerlerine yerleştirildi. $37^{\circ}$ $C^{\prime}$ de inkübe edildi.

Çalışmanın ikinci basamağı için yeniden hazırlanan $10 \%$ $\mathrm{w} / \mathrm{v}$ nistatin içeren diksler zamanla antifungal etkinin değerlendirilmesi için farklı süreler (1, 7, 14, and 16 gün) boyunca su içinde bekletildiler. Daha sonra sudan çıkarılıp, C. albicans inoküle edilmiş SDA plağına yerleştirildiler. Her gruba nistatin veya $\mathrm{TiO}_{2}$ içermeyen bir kontrol diski yerleştirildi.

Bulgular: Uygulanan varyans analizi sonucu kontrol disklerinde istatistiksel olarak anlamlı bir $C$. albicans inhibisyonu yoktu $(p<0.001)$. In vitro olarak nistatin'in toz formunun yumuşak astarlara eklenmesi, $C$. albicans kolonizasyonunu önledi. Disklerin suda bekleme süresi, inhibisyon derecesini etkiledi. Fakat, yumuşak astarlara $\mathrm{TiO}_{2}$ ilavesi, C. albicans kolonizasyonunu önlemedi.

Sonuç: Bu çalışmanın sonucuna göre, in vitro olarak, nistatinin toz formunun yumuşak astarlara ilave edilmesi, C. albicans kolonizasyonunu önledi fakat aynı miktardaki $\mathrm{TiO}_{2}$ tozu eklenmesi etki göstermedi.

Anahtar Kelimeler: Nistatin, titanyum dioksit, Candida albicans

\section{ABSTRACT}

Aim: Soft liners can support the adhesion and colonization of Candida albicans, which can then irritate the mucosa of denture wearers, resulting in the formation of lesions. The goal of this study was to evaluate the efficacy of fungicidal agents, nystatin and titanium dioxide $\left[\mathrm{TiO}_{2}\right]$, in preventing the colonization by Candida albicans on soft lining materials.

Material and methods: Disks of Ufi Gel P and Mollosil cold-curing, soft relining materials with a diameter of 5 $\mathrm{mm}$ and thickness of $2 \mathrm{~mm}$ were prepared with nystatin and $\mathrm{TiO}_{2}$ powders in a concentration of $5 \%, 10 \%$, and $15 \%(w / v)$. For the control group, only discs not containing nystatin and $\mathrm{TiO}_{2}$ were prepared, which consisted only of soft lining material. C. albicans was inoculated on Sabouraud dextrose agar (SDA)-coated plates. The disks were placed on these plates and incubated aerobically at $37^{\circ} \mathrm{C}$.

The Ufi Gel P and Mollosil disks, including $10 \% \mathrm{w} / \mathrm{v}$ nystatin, (re-prepared for the second step of the study) were immersed in water for separate intervals $(1,7,14$, and 16 days) to determine the fungicidal action over time. The disks were then removed and placed on SDA plates inoculated with $C$. albicans. In each group, one control disk without nystatin or $\mathrm{TiO}_{2}$ was included.

Results: A univariate analysis of variance test revealed that the activity of $C$. albicans was not significantly inhibited on the control disks $(p<0.001)$. The addition of nystatin in powder form to the soft liners prevented the colonization of $C$. albicans in vitro. The immersion time of the disks plunged in water appeared to affect the degree of inhibition. However, the addition of $\mathrm{TiO}_{2}$ did not prevent colonization by $C$. albicans of the soft liners.

Conclusion: This study showed that the addition of nystatin in powder form to soft liners prevented the colonization of $C$. albicans in vitro but that the addition of the same amount of $\mathrm{TiO}_{2}$ powder did not.

Keywords: Nystatin, titanium dioxide, Candida albicans

\footnotetext{
* Atatürk Üniversitesi, Diş Hekimliği Fakültesi, Protetik Diş Tedavisi AD.
} 


\section{INTRODUCTION}

Candida albicans in the oral cavity can cause denture stomatitis, which is a common oral infection of denture-bearing mucosa. ${ }^{1}$ Denture stomatitis, also known as denture sore mouth, is a common problem in the maxilla of complete denture wearers and a palatal defect prosthesis. ${ }^{2}$ According to the literature, this condition occurs in between $11 \%$ and $67 \%$ of denture wearers..$^{3-5}$ Local factors associated with dentures are also connected with denture stomatitis, such as the presence of a biofilm, ${ }^{6-9}$ local trauma caused by dentures ${ }_{1}^{10}$ xerostomia, ${ }_{1}^{11}$ continuous use of dentures, ${ }^{12}$ and alteration in the salivary $\mathrm{pH}^{12}$ Soft denture liners, namely soft polymers, can be applied to the mucosal or fitting area of the dentures. Soft liners diminish occlusal forces ${ }^{4}$ and traumatic effects of dentures on the mucosa. They may be used in patients with resorbed ridges, deep anatomic undercuts, bony protuberances, and sharp alveolar ridge crests. ${ }^{12}$ They may also be used in cases where the oral mucosa displays decreased toleration to the load imposed by the denture and in those with congenital and acquired oral defects requiring obturation. ${ }^{4,13-15}$ The use of these soft lining materials results in a more uniform dispersion of stress in the mucosa-lining interface with the denture. ${ }^{15}$ Both temporary and permanent silicone rubber and acrylic resin liners are available. ${ }^{15,}{ }^{16}$ In the infirm, silicone materials are useful due to their stability, whereas in contrast, acrylic materials are less stable, losing their cushioning effect over time. ${ }^{14,17}$

Those polymerized at room temperature, the usage times vary between a few weeks and a few months. C. albicans is a eukaryotic, opportunistic pathogen that can easily colonize silicone materials. ${ }^{1{ }^{1}}$ The ease of colonization by C. albicans is thought to be due to the nature of the material and the difficulty in mechanically and chemically cleaning the liner. $^{18}$ Mechanical cleaning is particularly difficult in patients with reduced motor function. Several investigations showed that the antimicrobial effect of nystatin supplemented tissue conditioners ${ }^{19,20}$ and soft denture liners. ${ }^{21,22}$ Titanium dioxide $\left(\mathrm{TiO}_{2}\right)$ powder has also been shown to have antimicrobial and antifungal properties and to increase the antimicrobial (versus $C$. albicans and Streptococcus mutans) properties of resin. ${ }^{23} \mathrm{TiO}_{2}$ mixed with tissue conditioner also appeared to exhibit antifungal activity against $C$. albicans, ${ }^{24}$ however, there are a limited number of studies in the literature on this subject. The best way to understand the effectiveness of titanium dioxide is to compare it with nystatin. There is no study aiming at a comparison between $\mathrm{TiO}_{2}$ and nystatin powders to evaluate increasing the fungicidal action of soft liners.

The aim of this study was to examine the colonization by $C$. albicans of soft liners, Ufi Gel P and Mollosil, impregnated with nystatin and $\mathrm{TiO}_{2}$ powders. An additional aim was to determine whether the fungicidal action decreased following immersion in an aqueous environment for an extended interval. To determine the colonization by $C$. albicans, the mean diameter of the inhibition areas was measured in experimental and control groups. The resulting data can shed light on the effectiveness of nystatin and $\mathrm{TiO}_{2}$. The hypothesis of this study was that increases in fungicidal action of soft liners should be expected due to the added fillers.

\section{MATERIAL AND METHODS}

There were two stages in this in vitro investigation. The first step assessed the influence of $5 \%, 10 \%$, and $15 \% \mathrm{w} / \mathrm{v}$ nystatin (Fungostatin, Nobelfarma Laboratories) and $\mathrm{TiO}_{2}$ (Sigma-Aldrich) powders combined in different dosages in two relining materials ((Ufi Gel P (Voco Germany, Lot:1638354) and Mollosil, (Detax, Germany, Lot:171102)) on colonization by $C$. albicans. In the second step, the attachment and colonization activity of C. albicans were evaluated following immersion of the liners impregnated with nystatin in water for extended intervals.

Step 1. C. albicans (ATCC 10231) was stored at $-80^{\circ}$ C. Yeast isolate was subcultured onto Saboraud dextrose agar (SDA) and incubated at $37^{\circ} \mathrm{C}$ for $48 \mathrm{~h}$. Colonies of $48 \mathrm{~h}$ cultures were then suspended in $5 \mathrm{ml}$ of a purged-saline solution. A McFarland 0.5 standard was used for the preparation of the inoculum, and $0.1 \mathrm{ml}$ of the inoculum was dripped on to the agar and diffused over the entire area.

Two types of silicone-based soft lining materials were chosen: a room-temperature polymerized Ufi Gel $\mathrm{P}$ and Mollosil. In order to

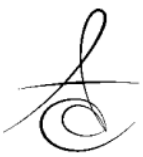


fabricate the disk liners, $5 \mathrm{~mm}$-diameter and $2 \mathrm{~mm}$ thick Teflon molds were used. The nystatin oral powder and the $\mathrm{TiO}_{2}$ powder were measured with a weighing machine and an analytical scale. The powder doses were as follows: 300,000 U, 200,000 U, 100,000 $\mathrm{U}$, and $0 \mathrm{U}$ (control) (Table 1). While the siliconebased soft lining materials (Ufi Gel $P$ and Mollosil) were prepared in accordance with the manufacturer's instructions, the nystatin and $\mathrm{TiO}_{2}$ powders added separately into the soft liners at concentrations of 5 , 10 , and $15 \% \mathrm{w} / \mathrm{v}$ in an aseptic plate. The mix (powder and soft liner) was then added to the mold and placed on a glass plate. A second glass plate was placed on the material to remove excess material from the mold. Pressure was applied, with the sample preserved under $1 \mathrm{~kg}$ pressure for $10 \mathrm{~min}$ at $25^{\circ} \mathrm{C}$. Later, the sample was removed from the mold and surplus residue was scraped off with a scalpel. There were four specimens in each plate and three disks were treated with each of the different concentrations of the powders. Soft liners united with reference to the producer's instructions with no incorporated active fungicide were used as a control. Nine specimens of each lining material and each powder were prepared in Step 1. The test and control disks were placed on seeded SDA. Identical plates were produced for each of the different concentrations of the fungicidal agents and the plates were incubated aerobically for $24 \mathrm{~h}$ at $37^{\circ} \mathrm{C}$ (Fig. 1). Following incubation, the diameters of the areas of inhibition of $C$. albicans were measured with calipers to the closest one-tenth of a millimeter. For each disk, three measurements were obtained and the average diameter was recorded.

Table 1. Drug dose integrated with the soft liners in observational groups

\begin{tabular}{|c|c|c|}
\hline Fungicidal factor & Drug dose & Equivalence in this study \\
\hline None (control) & None & \\
\hline Nystatin or $\mathrm{TiO}_{2}$ & $100.000 \mathrm{U}$ & $5 \% \mathrm{w} / \mathrm{v}$ \\
\hline Nystatin or $\mathrm{TiO}_{2}$ & $200.000 \mathrm{U}$ & $10 \% \mathrm{w} / \mathrm{v}$ \\
\hline Nystatin or $\mathrm{TiO}_{2}$ & $300.000 \mathrm{U}$ & $15 \% \mathrm{w} / \mathrm{v}$ \\
\hline
\end{tabular}

Step 2. $\mathrm{TiO}_{2}$ was not used in this step because it was ineffective in Step 1. The soft liners were prepared with $10 \%(\mathrm{w} / \mathrm{v})$ nystatin. The disks were individually plunged into $10 \mathrm{ml}$ of sterile-purified water and then stored at $37^{\circ} \mathrm{C}$, with the water being changed once every $24 \mathrm{~h}$. They were examined at 0 , $1,7,14$, and 16 days after immersion. The disks were then removed from the water and placed in sterile- purified water again to remove any traces of fluid, including surplus fungicidal powder, followed by blotting on aseptic blotting paper to remove excess fluid and placed on SDA plates inoculated with $C$. albicans. Soft liner specimens freshly mixed without the fungicidal agents were used as a control. Besides these three disks, one negative control disk was used on each plate. The plates were then incubated for 24 $\mathrm{h}$ at $37^{\circ} \mathrm{C}$. The dimension of the inhibition area was measured after $24 \mathrm{~h}$, as described in Step 1 . Univariate analysis of variance was used to evaluate statistical differences between the experimental groups.

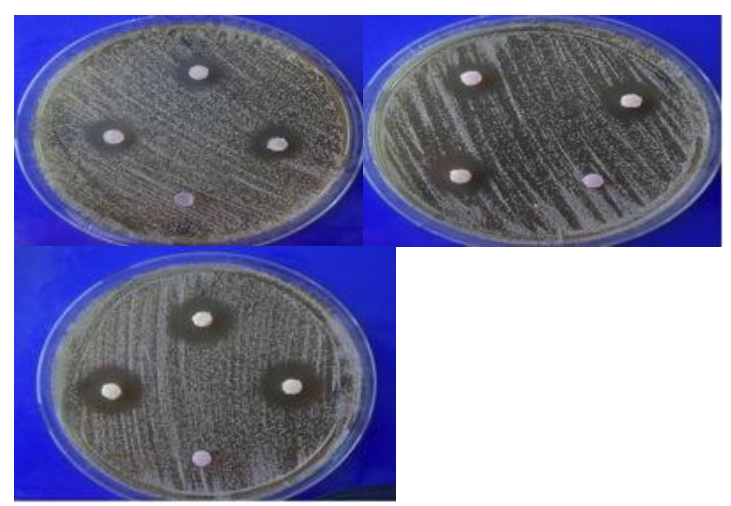

Figure 1. Examining disks and a control disk on SDA plate after incubation for $24 \mathrm{hrs}$. (a: 5\%, b: 10\%, c: 15\%w/v nystatin).

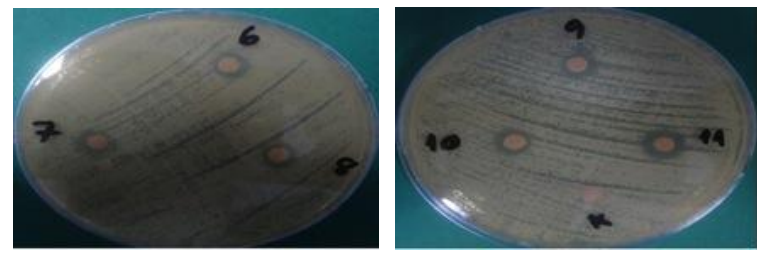

Figure 2. Examining disks and a control disk on SDA plate after incubation for $24 \mathrm{hrs}(10 \% \mathrm{w} / \mathrm{v}$ nystatin and after 16 days' immersion intervals for Ufi Gel P (a) and Mollosil (b)).

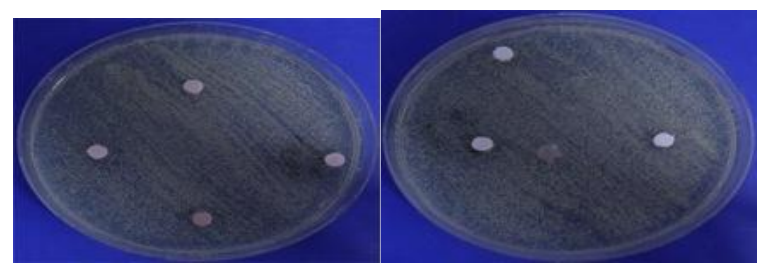

Figure 3. Examining disks and a control disk on SDA plate after incubation for $24 \mathrm{hrs}$ (a: $10 \%$, b: $15 \% \mathrm{v} / \mathrm{v} \mathrm{TiO}_{2}$ ).

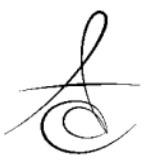




\section{RESULTS}

The diameter of the mean inhibition area was significantly different in the nystatin added-test disks compared with that of the controls $(p<0.01$, ANOVA). The diameter of the inhibition area around the soft liners treated with nystatin increased with a rise in the concentration of the fungicidal agent (Fig. $1)$, differing significantly $(p<0.001)$ according to the varying concentrations ( $5 \%, 10 \%$, and $15 \% \mathrm{w} / \mathrm{v})$ of the nystatin applied. The diameter of the inhibition area was unaltered in the soft liners treated with $\mathrm{TiO}_{2}$ (Fig. 3)

The dimensions of the inhibition zones in the disks plunged into distilled water for different intervals are illustrated in Table 2 and Figure 2. No significant differences were observed between days 0 and 1 and between days 14 and 16, but some significant differences were observed on day 7 and day 14 ( $p<$ 0.001 ). From linear regression, the diameters of the restriction areas showed an inverse correlation with time $(p<0.001)$.

Table 2. Mean diameters of restriction areas around disks of $10 \% \mathrm{v} / \mathrm{v}$ nystatin integrated with soft liners following dissimilar intervals in excess water

\begin{tabular}{|c|c|c|}
\hline Periods (day) & Ufi gel disks (mm) & Mollosil disks (mm) \\
\hline 0 & 14.4 & 15.4 \\
\hline 1 & 14.6 & 14.9 \\
\hline 7 & 11.4 & 11.5 \\
\hline 14 & 10.0 & 9.7 \\
\hline 16 & 9.5 & 9.5 \\
\hline
\end{tabular}

At all the concentrations tested, nystatin completely inhibited the attachment and colonization of $C$. albicans, however, in contrast, the controls were readily colonized by $C$. albicans (Table 1 ; ANOVA, $p>$ 0.05).

There was no significant difference $(p>0.05)$ between the Ufi Gel $\mathrm{P}$ and Mollosil materials.

\section{DISCUSSION}

There was increased fungicidal action of nystatin-supplemented soft liners, which supports the first part of this study's hypothesis. However, fungicidal action of $\mathrm{TiO}_{2}$-supplemented soft liners was not supported, which is the second part of the hypothesis.
Although the etiology of denture stomatitis is multifactorial, infection by opportunistic Candida spp., especially $C$. albicans, is a major cause. ${ }^{6}$ Several in vitro and in vivo studies demonstrated that the integration of fungicidal factors into tissue conditioners are useful and practical for the inhibition or prevention of plaque formation and improved recovery in denture stomatitis. ${ }^{6,21,25-29}$ Gruber et al. ${ }^{30}$ reported that silicone tissue conditioners and soft liners impregnated with zinc undecylenate eliminated colonization by Candida. In microbiological assays, nystatin restricted the emergence of $C$. albicans when it was used with a tissue conditioner. ${ }^{24,30}$ Some researchers added nystatin to the material as a fungicidal factor. Douglas and Walker ${ }^{21}$ showed that the tissue conditioners repressed colonization when used with nystatin and validated their findings in an in vivo study. In an in vitro study, a combination of ketaconazole and tissue conditioner restricted the colonization of Candida. ${ }^{31}$ $\begin{array}{lll}\text { Nystatin }(500,000 & \text { U) } \\ \text { combined with tissue }\end{array}$ conditioners was shown to impede the emergence of C. albicans, as were the fungicidal agents miconazole and ketoconazole. ${ }^{28}$ In a study of the antimycotic action of nystatin-impregnated soft denture lining materials and the influence of an aqueous environment on the fungicidal characteristics, Truhlar et al. $^{6}$ showed that doses of $1,000,000 \mathrm{U}$ and 500,000 $\mathrm{U}$ were useful in maintaining the drug-leaching quantity above the minimum inhibitory concentration for antifungal action. Radnai et al. ${ }^{12}$ demonstrated that miconazole gel, combined with a Viscogel tissue conditioner, restricted the emergence of $C$. albicans in vitro. In their study, the level of inhibition rose with an increase in the concentration of miconazole. However, when immersed in aseptic water for increased periods, the effectiveness of the miconazole-Viscogel combination declined. Various studies have examined the benefit of a range of materials, such as tissue conditioners and soft liners impregnated with fungicidals, for denture stomatitis. In vitro studies showed that a combination of ketoconazole and the tissue conditioner Viscogel eliminated Candida from dentures and that this effect was sustained for long periods. Another in vitro study examined a sustainedrelease delivery system for denture stomatitis. ${ }^{32}$ The system consisted of four fungicidal agents (chlorhexidine, clotrimazole, fluconazole, and nystatin) and a tissue conditioner, with the agents added at 
high, medium, and low concentrations. All the drugs were released by the tissue conditioner and restricted the growth of Candida; the best performance was observed using nystatin. ${ }^{32}$

Various treatments are available for denture stomatitis, including topical fungicidal and systemic therapy, oral hygiene, and denture hygiene, ${ }^{8,33}$ in addition to the replacement of old dentures, treatment of anatomic disorders, re-establishment of a traumatic occlusion, and nutritional restitution. ${ }^{34}$ The removal of dentures while sleeping can also help to maintain the health of the mucosal epithelium. ${ }^{31}$ Patients with denture stomatitis may require one or more treatments as re-infection of treated oral mucosa may occur up to 2 weeks after treatment because of the survival of Candida spp. owing to an insufficient concentration of the fungicidal agent on the surface of the dentures. Thus, various methods are used to eliminate microorganisms from the surface of dentures. ${ }^{8}$ Martínez-Beneyto et al. ${ }^{35}$ showed that the most recommended fungicidal agent was miconazole (prescribed by $59.3 \%$ of the survey's respondents), followed by nystatin $(57.7 \%)$ for topical use. Uchimaru et $\mathrm{al}^{24}$ reported that $\mathrm{TiO}_{2}$, which is a stable photocatalyst, combined with a tissue conditioner exhibited antimicrobial activity against Escherichia coli, S. mutans, and S. aureus, and antifungal activity against $C$. albicans. $\mathrm{TiO}_{2}$ exhibits strong oxidizing power under UV radiation (from sunlight or an illuminated light source) ${ }^{36}$ but no photocatalystic effects at nonradiation, ${ }^{37,38}$ which means soft liners with $\mathrm{TiO}_{2}$ may have no antifungal effect in the oral cavity environment. ${ }^{38}$ When dentures are removed, for instance during sleep, the photocatalystic agents can allow for the maintenance of soft liners by radiation alone. ${ }^{38}$ The current study did not use UV radiation in the oral cavity environment, which may explain why the results differ from other studies. Another possible reason is that the powder's micron particle size is in contrast to some other studies, which used nanoparticles. ${ }^{37,38}$ Nystatin was shown to be as effective as a Candida growth inhibitor, but no consensus was reached on the best concentration of nystatin. ${ }^{22}$ The present study found that $300,000 \mathrm{U}$ was the most effective concentration of nystatin, therefore nystatin may be a good choice to prevent colonization of Candida albicans on soft liners. Because of the usage times of this type soft liners vary between a few weeks and a few months, we think that nystatin addition will extend the maximum usage period.

However, $\mathrm{TiO}_{2}$ was not effective at the same concentration. Song et al. ${ }^{23}$ used the film adhesion method to test the antimicrobial activity of the samples against Streptococcus mutans and $C$. albicans. The test method used in the current study might account for the difference in observed results. New in vivo and in vitro studies can be performed using different test methods.

\section{CONCLUSION}

Soft lining materials impregnated with $5-15 \%$ $\mathrm{w} / \mathrm{v}$ nystatin completely inhibited the adhesion and colonization of $C$. albicans. The level of inhibition was similar using Mollosil and Ufi Gel P. The addition of $\mathrm{TiO}_{2}$ did not appear to be effective in restricting colonization by $\mathrm{C}$. albicans.

Funda Bayındır, ORCID ID: 0000-0001-5699-2879

Esra Kul , ORCID ID: 0000-0003-4750-8955

Esin Aktas,, ORCID ID: 0000-0002-8078-2780

Ayşe Baştopçu, ORCID ID: 0000-0003-1633-2627

\section{KAYNAKLAR}

1. Nikawa $H$, Iwanaga $H$, Kameda $M$, Hamada $T$. In vitro evaluation of Candida albicans adherence to soft denture-lining materials. J Prosthet Dent 1992;68:804-8.

2. Razek MK, Mohamed ZM. Influence of tissueconditioning materials on the oral bacteriologic status of complete denture wearers. J Prosthet Dent 1980;44:137-42.

3. Arendorf TM Walker DM. Denture stomatitis: a review. J Oral Rehabil 1987;14:217-27.

4. Vural C, Ozdemir G, Kurtulmus H, Kumbuloglu O, Ozcan M. Comparative effects of two different artificial body fluids on Candida albicans adhesion to soft lining materials. Dent Mater J 2010;29:206-12.

5. Budtz-Jørgensen $E$, Theilade $E$, Theilade J. Quantitive relationship between yeasts and bacteria in denture-induced stomatitis. Scand J Dent Res 1983;91:134-42. 
6. Truhlar MR, Shay K, Sohnle P. Use of a new assay technique for quantification of antifungal activity of nystatin incorporated in denture liners. J Prosthet Dent 1994;71:517-24.

7. Budtz-Jorgensen E, Bertram U. Denture stomatitis. I. The etiology in relation to trauma and infection. Acta Odontol Scand 1970;28:7192.

8. Alcantara $\mathrm{CS}$, Macedo $\mathrm{AF}$, Gurgel $\mathrm{BC}$, Jorge $\mathrm{JH}$, Neppelenbroek $\mathrm{KH}$, Urban VM. Peel bond strength of resilient liner modified by the addition of antimicrobial agents to denture base acrylic resin. J Appl Oral Sci 2012;20:607-12.

9. Banting DW, Greenhorn PA, McMinn JG. Effectiveness of a topical antifungal regimen for the treatment of oral candidiasis in older, chronically ill, institutionalized, adults. J Can Dent Assoc 1995;61:199-200, 203-5.

10. Arendorf TM, Walker DM. Oral candidal populations in health and disease. $\mathrm{Br}$ Dent J 1979;147:267-72.

11. Torres SR, Peixoto CB, Caldas DM, Silva EB, Akiti $T$, Nucci $M$, et al. Relationship between salivary flow rates and Candida counts in subjects with xerostomia. Oral Surg Oral Med Oral Pathol Oral Radiol Endod 2002;93:149-54.

12. Radnai M, Whiley R, Friel T, Wright PS. Effect of antifungal gels incorporated into a tissue conditioning material on the growth of Candida albicans. Gerodontology 2010;27:292-6.

13. Williamson RT. Clinical application of a soft denture liner: a case report. Quintessence Int 1995;26:413-8.

14. Pavan S, dos Santos PH, Filho JN, Spolidorio DM. Colonisation of soft lining materials by microorganisms. Gerodontology 2010;27:211-6.

15. Braden M, Wright PS, Parker S. Soft lining materials--a review. Eur J Prosthodont Restor Dent 1995;3:163-74.

16. Qudah S, Harrison A, Huggett R. Soft lining materials in prosthetic dentistry: a review. Int J Prosthodont 1990;3:477-83.

17. Murata H, Taguchi N, Hamada T, Kawamura M, McCabe JF. Dynamic viscoelasticity of soft liners and masticatory function. J Dent Res 2002;81:123-8
18. Murata $\mathrm{H}$, Hong $\mathrm{G}$, Li YA, Hamada $\mathrm{T}$. Compatibility of tissue conditioners and dental stones: effect on surface roughness. J Prosthet Dent 2005;93:274-81.

19. Chow CK, Matear DW, Lawrence HP. Efficacy of antifungal agents in tissue conditioners in treating candidiasis. Gerodontology 1999;16:1108.

20. Geerts GA, Stuhlinger ME, Basson NJ. Effect of an antifungal denture liner on the saliva yeast count in patients with denture stomatitis: a pilot study. J Oral Rehabil 2008;35:664-9.

21. Douglas $\mathbf{W H}$, Walker DM. Nystatin in denture liners - an alternative treatment of denture stomatitis. Br Dent J1973;135:55-9.

22. Skupien JA, Valentini F, Boscato N, Pereira-Cenci T. Prevention and treatment of Candida colonization on denture liners: a systematic review. J Prosthet Dent 2013;110:356-62.

23. Song $R$, Jiao $X$, Lin $L$. Improvement of mechanical and antimicrobial properties of denture base resin by nano-titanium dioxide and nanosilicon dioxide particles. Pigment and Resin Technology 2011;40:393-8.

24. Uchimaru M, Sakai T, Moroi R, Shiota S, Shibata Y, Deguchi M, Sakai H, Yamashita Y, Terada Y. Antimicrobial and antifungal effects of tissue conditioners containing a photocatalyst. Dent Mater J 2011;30:691-9.

25. Urban VM, de Souza RF, Arrais CA, Borsato KT, Vaz LG. Effect of the association of nystatin with a tissue conditioner on its ultimate tensile strength. J Prosthodont 2006;15:295-9.

26. Patel MP, Cruchley AT, Coleman DC, Swai H, Braden M, Williams DM. A polymeric system for the intra-oral delivery of an anti-fungal agent. Biomaterials 2001;22:2319-24.

27. Falah-Tafti $A$, Jafari $A A$, Lotfi-Kamran $M H$, Fallahzadeh $\mathrm{H}$, Hayan RS. A comparison of the efficacy of nystatin and fluconazole incorporated into tissue conditioner on the in vitro attachment and colonization of Candida albicans. Dent Res J 2010;7:18-22. 
28. Quinn DM. The effectiveness, in vitro, of miconazole and ketoconazole combined with tissue conditioners in inhibiting the growth of Candida albicans. J Oral Rehabil 1985;12:177-82.

29. Bal BT, Yavuzyılmaz H. Yumuşak astar maddeleri. Atatürk Üniv Diş Hek Fak Derg 2006;Suppl 1:5360.

30. Gruber RG, Lucatarto EM, Molnar EJ. Fungus growth on tissue conditioners and soft denture liners. Rev Dent Liban 1968;18:36-43.

31. Carter GM, Kerr MA, Shepherd MG. The rational management of oral candidosis associated with dentures. N Z Dent J 1986;82:81-4.

32. Schneid TR. An in vitro analysis of a sustained release system for the treatment of denture stomatitis. Spec Care Dentist 1992;12:245-50.

33. Montagner $\mathrm{H}$, Montagner $\mathrm{F}$, Braun $\mathrm{KO}$, Peres $\mathrm{PE}$, Gomes BP. In vitro antifungal action of different substances over microwaved-cured acrylic resins. J Appl Oral Sci 2009;17:432-5.

34. Aldana L, Marker VA, Kolstad R, Iacopino AM. Effects of Candida treatment regimens on the physical properties of denture resins. Int J Prosthodont 1994;7:473-8.

35. Martínez-Beneyto Y L-JP, Velandrino-Nicolás A, Jornet-García V. Use of antifungal agents for oral candidiasis: results of a national survey. Int $\mathrm{J}$ Dent Hyg 2010;8:47-52.

36. Sivakumar I, Arunachalam KS, Sajjan S, Ramaraju AV, Rao B, Kamaraj B. Incorporation of antimicrobial macromolecules in acrylic denture base resins: a research composition and update. J Prosthodont 2014;23:284-90.

37. Sawada T, Sawada T, Kumasaka T, Hamada N, Shibata T, Nonami T, Kimoto K. Self-cleaning effects of acrylic resin containing fluoridated apatite-coated titanium dioxide. Gerodontology 2014;31:68-75.

38. Akiba N, Hayakawa I, Keh ES, Watanabe A. Antifungal effects of a tissue conditioner coating agent with $\mathrm{TiO} 2$ photocatalyst. J Med Dent Sci 2005;52:223-7.

\section{Yazışma Adresi}

Yrd. Doç. Dr. Esra KUL

Atatürk Üniversitesi

Diş Hekimliği Fakültesi, Protetik Diş Tedavisi AD

Erzurum

TIf; 2311684

e-mail: esra.kul@atauni.edu.tr 